\begin{tabular}{|l|l|}
\hline Journal Code: PSR & Proofreader: Mony \\
\hline Article No: PSR12047 & Delivery date: 20 Dec 2013 \\
\hline Page Extent: 11 & \\
\hline
\end{tabular}

POLITICAL STUDIES REVIEW: 2014

doi: $10.1111 / 1478-9302.12047$

\title{
Between the Waves: Currents in Contemporary Feminist Thought
}

\author{
Ros Hague \\ Nottingham Trent University
}

With a continuing focus on liberal feminism, Marxist feminism and essentialism, one would be forgiven for thinking that feminist theory is unable to break free from the 'second wave'. This is not the case. This article reviews three books which take on these feminist issues and offer new readings on the questions at the heart of feminism. Each provides clear links to feminism of the past but also connects to present debate and makes suggestions for future directions for feminism. There is plenty of literature which bemoans the end of feminism and some which triumphantly hails our era as post-feminist: no longer in need of feminist theory. Contrary to such claims, each book tackles the problem of women's oppression from a different perspective, each presents different solutions and in so doing they demonstrate that feminism is alive and well.

Abbey, R. (2011) The Return of Feminist Liberalism. Durham: Acumen.

Weeks, K. (2011) The Problem with Work: Feminism, Marxism, Antiwork Politics and Postwork Imaginaries. Durham, NC: Duke University Press.

Witt, C. (2011) The Metaphysics of Gender. Oxford: Oxford University Press.

Keywords: feminism; essentialism; liberal feminism; Marxist feminism; gender

The three books reviewed here engage with ideas rooted in earlier thinking (liberal feminism, Marxist feminism and essentialism), but they provide innovative critical perspectives and new types of evidence in an ongoing debate over issues which simply will not and should not go away. They advance feminist works of the late 1990s and early 2000s in rejecting and moving beyond the binary categorisations of equality/difference, sex/gender and public/private (see, e.g., Hutchings, 2003; Prokhovnik, 2002).

There is considerable debate over 'where feminism is at', especially in the literature dealing with key concerns of 'third wave feminists' (Budgeon, 2011; Gillis et al., 2005). An apparent rupture between 'third and second wavers' (Siegel, 2007) is under debate, while Clare Hemmings (2005) provides a critique of how the overall history of feminism is represented. Both Deborah Siegel and Hemmings highlight the importance of the relationship between ongoing feminist concerns and earlier theories. A perennial problem for second wave feminism was the question of women's identity: should feminism treat women as a group? This approach was criticised for its tendency towards the exclusion of some women and for taking the experience of white, Western, middle-class women to be the common experience of all women. What then of the alternative approach - to treat women as individuals rather than as one group? This, a largely liberal feminist approach, was criticised for its abstraction of women from their real experience of everyday life, denying the significance of any particular identity and the possibility that different women will experience the same phenomenon differently. The question of women's identity has been visited in several interrelated forms in the second wave: 
essentialism (a debate on whether or not women share common features by virtue of being a woman), intersectionality (the argument that sex-based oppression does not occur separately to or exclusively from other socially and culturally constructed categories such as race or class) and the shifting focus from equality to difference (tackling inequality requires respect for difference and diversity among women). These issues of identity remain key themes for feminist theory. For Hemmings the story of feminism should not be the story of one school of thought displacing another; rather we should draw links between the common feminist features of these approaches and treat feminism 'as a series of ongoing contests and relationships' (Hemmings, 2005, p. 131). That feminist theorising is diverse and multifaceted should be seen as a good thing, and the three books discussed here show that there are still important political issues which demand the attention of feminists. In different ways, they demonstrate that political and social problems, and responses to them, do not rise up out of a void, but are part of an ongoing conversation with the feminist theory of the past, upon which may be built theories about the future. Most of all, they either directly or indirectly refute the claims of 'post-feminism', the notion that we somehow live in 'post-patriarchy' (Siegel, 2007, p. 126). In other words, they demonstrate that we still need feminist theory. More specifically, we need feminist theory to deal with its own problems - problems of which we are well aware, especially feminism's (in) ability to engage with the social and political oppression of all women. While it is not particularly useful to categorise feminist writing as either reformist or revolutionary, a dualism which, for example, Weeks (2011, p. 228) rejects, the books under consideration here do draw on both reformist and revolutionary ideas. However, they are much more than that; they are works which are actively concerned with processes of re-conceptualisation.

\section{The Metaphysics of Gender}

Charlotte Witt's argument in The Metaphysics of Gender is complex, but may be summarised as the claim that the social roles we occupy are unified by gender, gender is the function that organises our social roles, and gender is 'uniessential'. Witt enters the highly contested debate on essentialism with this book and she does so with a notion of essentialism taken from Aristotle. Gender (a function) is uniessential (a functional property) to social individuals (an entity) - what makes us who we are, as social individuals, is gender. Therefore, we have a number of social roles which we inhabit, often at the same time (e.g. parent, professional, friend), and these are united by one function: gender. Gender is a social norm and, as such, it unites the social roles we occupy and conditions our practical agency: the expectations and obligations which arise from our gender trump all others. This approach to essentialism is not the same as 'traditional' feminist debates on the subject. Alison Stone notes that arguments about essentialism have taken either a 'natural' or a socially constructed view of women 'whereby a particular pattern of social construction is essential and universal to all women' (Stone, 2007, p. 27, note 5). Both views came to be criticised because both ascribed 'necessary and common characteristics to all women' (Stone, 2007, p. 18). So essentialism in feminist theory has been concerned with a highly problematic search for some feature which all women share. However, Witt's concern is different; she aims to explore the metaphysics of essentialism. Her 
analysis demonstrates how gender norms are constituted, how our social roles are gendered in a variety of ways.

Our social positions depend on social recognition and this varies depending on both cultural and historical contexts (Witt, 2011, pp. 29-30). Witt argues that an individual is both responsive to, and evaluable under, a social norm. In being responsive, the individual (self-consciously or not) calibrates their behaviour according to a social norm: even when reacting against a norm, an individual can be understood to be responsive to it (Witt, 2011, pp. 31-2). Witt's account of social normativity is ascriptivist in that an individual is evaluated by social norms regardless of whether or not she identifies with them: even an individual who rebels against her social position is as responsive to, and evaluable under, that identity as is the individual who complies with it (Witt, 2011, p. 43). Witt argues that the account of ascriptivism is valuable to feminist theory for two reasons: (1) it explains why women appear subject to social norms regardless of whether or not they endorse them; and (2) feminist criticism should be directed against the norms themselves and 'restrictive social positions' (Witt, 2011, p. 47).

Witt separates the social individual from persons and from human organisms (together, these three form the self). Social individuals occupy a social position; in fact, we tend to occupy numerous social positions and we are all subject to the norms that go with these. Persons are individuals with a first-person perspective (they are self-conscious, can think for themselves) and 'a necessary condition for the possibility of autonomy' (Witt, 2011 , p. 54). Social individuals exist in the social world, but persons do not need a social world in order to exist (Witt, 2011, p. 56). The term 'human organism' refers to membership of the human species. The distinction between persons and social individuals is difficult to grasp and appears to rely on Witt's ascriptivist account of social normativity: identity is fixed by social position: it can be chosen, embraced, or it can be thrust upon us, and we merely react it to it (Witt, 2011, p. 63). Breaking down the self into three parts appears conceptually difficult and is, perhaps, unnecessary as the three are ineluctably linked and despite the capacity for self-reflection, the individual is a self who occupies a social position that is not of her choosing but which is ascribed to her by her culture or society (Witt, 2011, p. 126). The functions of a person are curtailed by those of the social individual. Critical reflection - the ability to think for ourselves - can be limited by our social location because gender essentialism is a social phenomenon and it takes place at the level of the social individual. For Witt, essentialism is not biological (at the level of organisms) because gender is a social construct and the liberal focus on our capacity for self-reflection (at the level of persons) does not rescue the self from essentialism because persons are not gendered - social individuals are (Witt, 2011, p. 58). This is a very brief discussion and Witt appears to feel it is sufficient to explain her notion of gender as being a distinctly social phenomenon. Witt does not fully engage with important thinkers in this debate. For example, on Witt's account identity is experienced by social individuals but seemingly chosen by persons. On this point engagement with some of the literature on gender and agency such as Butler's theory of gender as performance would have been useful (Butler, 1990; Lloyd, 2007). As it is, Butler's work gets only two brief mentions (on pp. 8 and 35). Witt acknowledges de Beauvoir's work ([1949]1997) on the social positions of men and of women, but does 
not go into any detail (Witt, 2011, p. 42). Witt's feminist argument appears to amount to the claim she makes on page 47 - that feminist criticism should be directed towards oppressive social norms - but she does not explain at any length how uniessentialism does this work.

Witt argues that the social role which unifies us is gender and not race. She conceives the unifying social role, or the 'mega social role', as that which organises 'fundamental social functions'. Our society is organised by patriarchy, and there 'are no fundamental social functions organized by race; we can see this by noting that the existence of races is variable: not all societies recognize racial differentiation, and not all of them recognize the same racial categories' (Witt, 2011, p. 102). Gender norms can be inflected by race, but gender is prior in its ability to define and to organise social roles. Witt argues that this view can be compatible with the literature on intersectionality and gives the following example: 'as Black feminists have noted, the issue of women in the workplace has an entirely different set of norms for Black women than it does for Caucasian women' (Witt, 2011, p. 101). However, this argument is rather brief and it fails to engage with intersectionality's criticism that there is a need 'to account for lived experience at neglected points of intersection - ones that tended to reflect multiple subordinate locations as opposed to dominant or mixed locations' (McCall, 2005, p. 1780), and more recent criticisms of what Mridula Nath Chakraborty calls 'hegemonic feminism' (Chakraborty, 2007). The notion of a 'mega' social role seems incompatible with the more nuanced accounts of intersectionality available.

While it may appear that Witt is covering some familiar territory, she does shine light on the metaphysics of this territory. Even so, it would have been interesting to see more engagement with some of the work on essentialism, and, most of all, Witt needed to do more to defend her claim that gender is the 'mega' social role she says it is. Surely the point of the intersectionality literature is that race is as significant as gender and certainly that women experience oppression in different ways. Although the latter point might fit with Witt's argument that, logically, women can experience oppression in different ways even though it is also a common experience because of the engendering social norm, it does not even skim the surface of the ways in which women oppress other women. Witt's rejection of race as a mega social role and the discussion of essentialism in feminist theory are both too cursory, and Ruth Abbey's approach to the literature on intersectionality is much more thorough.

\section{The Return of Feminist Liberalism}

Ruth Abbey's book provides in-depth analyses of the work of three contemporary feminists: Susan Moller Okin, Jean Hampton and Martha Nussbaum. ${ }^{1}$ Abbey argues that what unites these three thinkers is that their body of work operates within the parameters of liberalism, with each thinker working towards a reconfiguration of liberalism, rather than a rejection of it (Abbey, 2011, p. 4). Abbey acknowledges that, for each of her chosen subjects, there are problems with using liberalism for feminist purposes but, rather than reject liberalism because of its limitations, the goal of each thinker has been to reconfigure liberalism in order to make it compatible with feminism. She approaches the three authors' theories by analysing the ways in which Okin's work is used in that of 
Hampton and Nussbaum. Abbey contrasts Okin's advocacy of shared meanings with the universalism of liberalism. She argues that Hampton is an 'accidental contractarian' and that the 'real normative and theoretical work is done by her Kantian belief in the intrinsic worth of each person that should be respected in most human association' (Abbey, 2011, p. 3). With Nussbaum, Abbey examines the 'human capabilities approach' and scrutinises 'the problem that adaptive preferences pose for Nussbaum's feminist liberalism' (Abbey, 2011, p. 4). Abbey's review of feminist liberalism places Rawls at the centre of liberalism because of Okin's emphasis on the family and the basic structure, Hampton's contractarian and Kantian approach, and Nussbaum's political liberalism and capabilities approach (Abbey, 2011, p. 5). The engagement of these feminists with the work of Rawls can, according to Abbey, be understood as reciprocal: his work provides fertile ground for rethinking feminist liberalism (in the diverse ways listed above) but, in addition, these feminist criticisms of Rawls make a significant contribution to an assessment of his work and its legacy (Abbey, 2011, p. 6).

Abbey appears to argue that feminist liberalism is making a return because although liberalism has largely been dismissed by many feminists in recent decades, some have continued to find valuable aspects in liberalism for feminism (Abbey, 2011, p. 2). Abbey also notes a need for feminist theory to return to liberalism as it is, she argues, largely liberal values which have enabled feminist success in practice, here she points to achievements such as increased access for women to the workplace, political institutions and higher education (Abbey, 2011, pp. 7-8). Throughout, Abbey refers to 'feminist liberalism' rather than 'liberal feminism', and she provides three reasons for this. First, this is because the thinkers to whom she refers approach feminism as 'an extension of their liberalism' (Abbey, 2011, p. 8). Second, 'feminist liberalism' adopts a distinctly nonmasculine approach and seeks, for example, to apply 'liberal values across the publicprivate divide' (Abbey, 2011, p. 9). Finally, emphasis on 'feminist liberalism' helps to express the 'variety of forms contemporary liberalism takes' (Abbey, 2011, p. 9). Abbey highlights a number of points of connection between Okin, Hampton and Nussbaum, such as the demands they make of the state and their engagement with, and criticism of, the public-private divide. Abbey highlights one particular area of interest addressed by all three thinkers: diversity among women.

She reflects on the calls for equality made by Okin, Hampton and Nussbaum in the form of justice, moral personhood and global justice, but she is also critical of the ways in which these thinkers struggle to recognise differences among women in the pursuit of equality. She questions the degree to which Okin's work engages with such differences, and she argues that Okin should be more concerned with the literature on intersectionality because it is concerned with 'women's self-interpretations' - the idea that different women may experience the same phenomenon differently (Abbey, 2011, p. 98). Attention to women's self-interpretation fits with Okin's interest in using empirical work (women's self-interpretation would appear to be a valuable resource), her use of women's own experiences and understanding of their situation, and her Kantian insistence that women be understood, by themselves and others, as ends in themselves (Abbey, 2011, pp. 100-1). Abbey also finds that Hampton's work is unable to deal satisfactorily with the criticisms raised in the literature on intersectionality. She notes that Hampton's 
analysis of rape is Kantian rather than feminist, which means that for Hampton the act of rape is wrong because it ignores the right of the victim to be treated as a moral equal. This does not take into account self-interpretations, 'the meaning of rape can depend on particular features of the perpetrator(s) and the recipient' (Abbey, 2011, p. 138). Hampton's approach, Abbey argues, focuses on an abstract and universal argument that inequality, discrimination and violence against women are wrong because they do not respect the intrinsic worth of each human being (Abbey, 2011, p. 141).

Abbey finds Nussbaum guilty of making generalisations about women, or aggregating women's experiences (Abbey, 2011, p. 162). Although, in Nussbaum's defence, Abbey points out that Nussbaum 'seems to make room for attention to women's diverse self-interpretations' (Abbey, 2011, p. 164), she then cautions us to be aware of the problem of adaptive preferences in Nussbaum's work. Adaptive preferences arise from situations in which women face limited options and respond by becoming 'satisfied with, and attached to, what they have or can achieve, so that their stated preferences reflect their subordination and shrunken horizons' (Abbey, 2011, p. 174). This is similar to the problem Witt highlights - oppressive social positions can limit our capacity for selfreflection. It is a problem for feminist liberalism because free choice is valuable for liberals, but a feminist perspective also alerts us to the way oppression works to limit an individual's perception of what options are permitted in his/her subordinate social position (Abbey, 2011, pp. 174-5) and, therefore, some choices are open to critique. Abbey quotes Anne Phillips (2001): 'Nussbaum's dilemma reflects the fact that she is "simultaneously hooked on the idea of choice and critical of most people's choices", (Abbey, 2011, p. 176). There is a problem with divorcing intuitions about what is valuable from individual preferences - should we value preferences which could result from 'adaptation to injustice' (Abbey, 2011, p. 176)? Women appear to make choices which are not to their benefit and 'Okin, Hampton and Nussbaum advocate a range of techniques to rectify the fact that many women make choices that work to their disadvantage' (Abbey, 2011, p. 179). These techniques include demanding the state mandate equal pay or, less specifically, raising women's awareness of their equal moral worth (Abbey, 2011, p. 179).

Abbey argues that, for these thinkers, the overall category of 'women' is still useful because all women are oppressed in similar ways, but none of the thinkers denies the impact of factors such as race or poverty. These feminist liberals have the tools - in the form of moral individualism - to engage in a critique of all forms of oppression, 'for a society that permits individuals to be disadvantaged in these ways fails to respect the dignity and equal personhood of all its members' (Abbey, 2011, pp. 216-7). Whereas Witt sees a need for feminism to focus on the social roles of women, Abbey's emphasis is on individualism as a way of tackling women's inequality. In highlighting issues of intersectionality and of adaptive preferences, Abbey demonstrates the potential of feminist liberalism to deal with these feminist issues while maintaining liberal emphasis on individuality.

In her conclusion, Abbey acknowledges that there are 'shortcomings' to the way in which Okin, Hampton and Nussbaum address, or indeed fail to address, differences among women and argues that both their liberalism and their feminism demands that 
greater attention be paid to differences for four reasons. First, their rejection of a priori gendering of humans means not only that their feminist liberalism does not hold that women should be like men in order to qualify for moral consideration, but also that there can be no generalised standard for what it means to be a woman. Second, the liberal tradition in which these feminists work has been valuable to them because it supports 'the normative resources' with which to challenge unjust hierarchies and differences in power. It is, therefore, within the means of feminist liberals to challenge the unjust hierarchies to which the literature on intersectionality draws attention. Third, as has been noted, these theorists are Rawlsian feminist liberals and, as such, they should be concerned with women's self-interpretation in order to understand how this either fits or rubs up against principles of justice (after all, principles of justice should be accepted by all rather than imposed on some) (Abbey, 2011, p. 263). Abbey concludes this point with a warning: 'if feminist liberals fail to attend to women's diverse self-interpretations, they render themselves unable to consider how heavily their recommendations might fall on some members of society' (Abbey, 2011, pp. 269-70). And finally, incorporating differences between women calls on the mobilisation of the Kantian conception of the person: women need to see themselves as 'ends in themselves', and not means to the ends of others, and here Abbey argues that this 'is necessary but not sufficient for a change in women's self-understandings' (Abbey, 2011, p. 271). This position fits with her earlier criticism of Hampton for relying on this conception in her analysis of rape. Treating people as ends in themselves does not highlight how different women experience and interpret such acts differently.

For feminist liberals, then, the fact of women's oppression demands an emphasis on women's diverse experiences (while managing the problem of adaptive preferences) and an emphasis on women's moral equality with men. Part of the initial appeal of liberal feminism was its desire to achieve the 'achievable' to bring about women's rights, and the fact that its goals, now in the form of feminist liberalism, have to be less specific and have a broader focus does not mean that this version of feminism has lost its desire for reform. It still seeks to confront the patriarchal elements of liberalism, but it also means that feminism and liberalism continue to engage in a dialogue, challenging each other's theoretical views. Abbey's feminist liberalism is then involved in a process of theoretical dialogue between two evolving traditions: feminism and liberalism.

\section{The Problem with Work: Feminism, Marxism, Antiwork Politics and Postwork Imaginaries}

In The Problem with Work, Kathi Weeks combines feminist and non-feminist approaches in the form of Marxist, Marxist feminist and utopian thought. As the title suggests, feminism is one element of her analysis, and her focus on work and the way in which society functions around work also have strong implications for feminist theory - not least in the way in which she challenges the assumption that when alternatives to work are theorised, a common response is to turn to the family. This has obviously created limitations for women in terms of seeing their options located in either work or family.

Weeks' book addresses the concept of a 'postwork' society. She argues that we need to engage with the meaning of waged work not only because it is so significant to our 
lives (the means by which we acquire necessary goods - food, clothes and shelter), but because 'it is also the basic means by which status is allocated, and by which most people gain access to healthcare and retirement' (Weeks, 2011, p. 6). She goes on to argue that work is a process of subject making and, indeed, 'a site of gendering' (Weeks, 2011, p. 9). Work is organised through gender - 'the productivity of gender-differentiated labor' constructs the workplace and the home 'including the gendered division of the household roles and waged occupations' (Weeks, 2011, p. 9).

Weeks develops an argument for a 'postwork society' through a number of avenues including Weber's analysis of the Protestant work ethic (which she uses to expose the irrationality of that ethic), and two accounts of Marxism which she labels 'socialist modernization' and 'socialist humanism', both of which are rejected in favour of the autonomist Marxist tradition. Weeks also explores the Marxist feminist 'Wages for Housework' campaign, and the potential of utopian thought for advancing a postwork society. Of these, the latter three are given most attention and appear to be most significant to her argument.

Weeks' objection to Marx's critique of the work ethic, or the very idea of the work ethic, is that the alternative he provides is not an actual remedy to the system of which he is so critical. For Marx, work, albeit reformulated, remains necessary, and he does not posit an alternative (Weeks, 2011, p. 91). Accordingly, Weeks (2011, p. 92) turns to the autonomous Marxist tradition and, in particular, she draws on the work of Antonio Negri. She reads Negri as providing an alternative future in which work as it currently exists is rejected as a viable strategy and is instead transformed (Weeks, 2011, pp. 100-1). Weeks provides a reading of the 1970s Marxist feminist 'Wages for Housework' campaign and reworks it 'as a contemporary demand for guaranteed basic income' (Weeks, 2011, p. 113). She focuses particularly on the work of Mariarosa Dalla Costa and Selma James and argues that the demand for wages for housework was meant neither to 'celebrate' nor to 'sanctify' work which involved a rejection of the gendered division of labour and a refusal to engage with 'some all-too-familiar romanticization of the domestic realm's relations and rituals' (Weeks, 2011, p. 124). Weeks points out that those involved with the campaign 'rejected not only the capitalist but also the socialist remedies defended by other feminists at the time' (Weeks, 2011, p. 125). She argues that the Wages for Housework campaign interested Dalla Costa and James (1973) 'initially at least, as a mechanism for the development of feminist subjectivity' (Weeks, 2011, p. 127). Here she draws parallels with the project of autonomous Marxism. She also emphasises the power and potential of making a demand - something which is both a perspective (renders visible the issue of women's place in society) and a provocation (a call to action through various means such as commitment to a cause or formation of a collectivity) (Weeks, 2011, pp. 128-31).

For Weeks, the struggle against oppressive working hours should be considered part of the same demand as the struggle against the family structure of reproductive labour (Weeks, 2011, p. 152). Weeks, like Witt and Abbey, is returning to sites of contestation and disagreement and like the others she does so in order to move forwards. Weeks uses the refusal of work as a tool with which to reconfigure three aspects of Marxist feminism: 'publicising work, politicizing it and radically transforming it' (Weeks, 2011, 
p. 24). Publicising work involved drawing attention to reproductive labour - labour which was socially necessary but not financially rewarded. Publicising this drew attention to the fact that time spent outside (paid) work was not leisure time, it was unpaid work time. Yet even Marxist feminism did not go far enough in reconfiguring work, it challenged the organisation of work but it did not directly challenge the value placed on work (Weeks, 2011, p. 25), for a criticism of work's value, Weeks turns to Autonomous Marxism. Therefore, Weeks' project involves a reading of Marxist feminism, combined with the Autonomous Marxism literature, in so doing she reinvigorates Marxist feminism in general and the 'Wages for Housework' campaign in particular. In agreement with Hemmings, Weeks conceives the story of feminism as 'not only a story of progress but also sometimes ... of forgotten ideas and stifled aspirations' (Weeks, 2011, p. 117). She argues that her interest is in re-engagement with forgotten ideas to challenge the present 'and reinvigorate its possible futures' (Weeks, 2011, p. 117). Weeks argues for what she sees as a 'transfigurative politics' which contains the possibility for future subjectivity - 'a process of creating new subjectivities with new capacities and desires, and, eventually, new demands'. Time spent not working can be theorised as time which contains 'potential social productivity' (Weeks, 2011, p. 169). This opens up the possibility of imagining alternatives to the present 'dominant ideals' of both work and family (Weeks, 2011, p. 170). This, she argues, creates the possibility for a more inclusive feminism.

In her final chapter, Weeks shifts focus to the utopian potential of a demand for shorter working hours. Weeks analyses what she refers to as 'utopian artefacts', but she is also interested in the function of utopia (Weeks, 2011, p. 204). Weeks approaches this body of literature by analysing it in the context of two features: one of estrangement (which functions to 'alter our connection to the present'), and one of hope (which provides 'provocations toward alternatives' and therefore looks to the future) (Weeks, 2011, pp. 204-5). Estrangement takes us out of our setting and renders it unfamiliar: in so doing, it provides us with a point from which to engage critically with the present (Weeks, 2011, p. 205). The second function - hope - provokes a desire to act and inspires our political imagination. It also provides a force for mobilisation: 'utopias can serve as inspirational models; they can help to activate political will, to mobilize and organize movements for social change' (Weeks, 2011, p. 206). Weeks argues that utopian visions need not serve as blueprints, but they do 'do the work of estrangement and provocation' (Weeks, 2011, p. 211).

Weeks returns to the idea of making a demand. Inevitably, a demand is made in the realm of practical and, indeed, pragmatic politics (Weeks, 2011, p. 219), but a demand which is utopian is 'necessarily larger in scope' than a policy proposal (Weeks, 2011, p. 220). Weeks argues that the central idea of the utopian demand is that it can be both reformist and revolutionary (Weeks, 2011, p. 228). The refusal of work raises important questions for feminism, for what takes the place of the 'privatized family', and for the 'structures of production and reproduction' (Weeks, 2011, pp. 110-1). For Weeks the answer is 'life'. A demand for the reform of working hours and basic income is reformist, but championing "the political project of "life against work" is a general rubric within which to frame the kinds of antiwork critiques and postwork imaginaries represented here by the demands for basic income and shorter hours' (Weeks, 2011, p. 230). 
Accordingly, Weeks aims to juxtapose life with work (Weeks, 2011, p. 231) and this opens up a number of possibilities for thinking about future conceptions of work. The juxtaposition is an interesting idea, but it is given very little space.

Weeks' final chapter is perhaps the most engaging of the book and the notion of a utopian demand offers hope not only for Weeks' concept of a postwork society, but for feminist theory as a whole. Weeks' feminism combines the real with the possible and calls on the imagination to help in this process. The possibility of conceiving a future radically different from, but connected to, the present or, in the words of Catriona Mackenzie, 'imagining ourselves otherwise' (Mackenzie, 2000), is key to Weeks in the struggle against oppression. It could also be a route endorsed by Witt whose work highlights the problem of oppressive social roles, but then leaves to feminist theory the task of tackling them (Witt, 2011, p. 132).

\section{Conclusion}

The work of these three theorists involves a process of transformation, returning, re-conceptualisation and an ongoing belief that change is still possible. Contemporary feminism has taken on the issues of identity I raised in the introduction with essentialism being described by Jane Spencer as 'a battle constantly revisited' (Spencer, 2007, p. 300). Issues raised in the second wave which created arguments around intersectionality are being discussed in third wave criticisms of more recent attempts to create a universal identity of woman. For example, recent movements such as feminist punk movement 'Riot Grrrl' have drawn criticism for their failure to understand sexism in the wider context of racial and class oppression (Munford, 2007, p. 272). Finally, after the many challenges to the notion that 'woman' could ever be a homogenous group from Black, post-modern and post-structuralist feminists, contemporary feminism is very sensitive to diversity and difference. The three books reviewed here respond, to varying degrees, to these issues. Witt deals directly with essentialism, Abbey with the challenge of intersectionality for feminist theory and the means of incorporating diversity and difference. Weeks' book is a broader take on these themes: she provides a feminist analysis of work and the way in which it defines us as subjects. Each book returns to important features of the feminist debate (essentialism, liberal feminism and the Marxist feminist 'Wages for Housework' campaign) and in so doing each author demonstrates agreement with Hemmings' arguments that telling the story of feminism is not a story of displacement but is rather one of returning, reconceptualisation and reinvigorating these key feminist ideas. All tackle social roles and prescribed identity, Witt through the gendering of social roles, Abbey draws attention to the need for engagement with women's diverse self-interpretations and Weeks looks at the gendering of both work roles and non-work roles. In different ways, the books discussed here draw attention to future possibilities for feminism: the alteration of gender norms which are oppressive; feminist liberalism reinvigorated; utopian demands for a better life. There is no single feminist response to the problem of inequality: each of the thinkers frames the problem differently and, therefore, each posits different political solutions. In getting on with the task of doing feminist theory, these authors demonstrate that the problem feminism faces is not necessarily one of definition - it is the ongoing fact of women's oppression. The varied 
JOBNAME: No Job Name PAGE: 11 SESS: 11 OUTPUT: Fri Dec 20 17:33:57 2013 SUM: F19A4C71

/Xpp84/wiley_journal/PSR/psr_v0_i0/psr_12047

debates on how to tackle gender oppression are still flowing, regardless of whichever wave sets them down on our shore.

(Accepted: 2 November 2013)

\begin{abstract}
About the Author
Ros Hague is a Lecturer in the Division of Politics and International Relations at Nottingham Trent University. Her research covers two main areas: gender and the environment (specifically the attitudes to nature found in people who live and work with nature and also in fictional representations of nature). Her book Autonomy and Identity: The Politics of Who We Are (Routledge, 2011) looked at the concepts of autonomy and identity in order to develop a new, feminist, understanding which sees autonomy as a process by which we change and develop our identity. Ros Hague, Division of Politics and International Relations, School of Social Sciences, Nottingham Trent University, Burton Street, Nottingham NG1 4BU, UK; email: ros.hague@ntu.ac.uk
\end{abstract}

\title{
Notes
}

I am very grateful to Laura Brace and to the two anonymous reviewers for their helpful comments on an earlier draft of this article. Thanks also to Lucy Sargisson for suggesting I write this piece.

1 Hampton and Nussbaum have written specifically on feminism but also on other topics and Abbey confines her analysis to the former works.

\section{References}

Abbey, R. (2011) The Return of Feminist Liberalism. Durham: Acumen.

Beauvoir, S. de ([1949] 1997). The Second Sex. Trans. H. M. Parshley. London: Vintage.

Budgeon, S. (2011) Third Wave Feminism and the Politics of Gender in Late Modernity. Houndmills: Palgrave Macmillan.

Butler, J. (1990) Gender Trouble: Feminism and the Subversion of Identity. New York: Routledge.

Chakraborty, M. N. (2007) 'Wa(I)Ving It All Away: Producing Subject and Knowledge in Feminisms of Colours', in S. Gillis, G. Howie and R. Munford (eds), Third Wave Feminism: A Critical Exploration. Houndmills: Palgrave Macmillan, pp.e... ¿.

Dalla Costa, M. and James, S. (1973) The Power of Women and the Subversion of the Community. Bristol: Falling Wall.

Gillis, S., Howie, G. and Munford, R. (eds) (2007) Third Wave Feminism: A Critical Exploration. Houndmills: Palgrave Macmillan.

Hemmings, C. (2005) 'Telling Feminist Stories', Feminist Theory, 6 (2), 115-39.

Hutchings, K. (2003) Hegel and Feminist Philosophy. Cambridge: Polity Press.

Lloyd, M. (2007) Judith Butler: From Norms to Politics. Cambridge: Polity Press.

Mackenzie, C. (2000) 'Imagining Oneself Otherwise', in C. Mackenzie and N. Stoljar (eds), Relational Autonomy: Feminist Perspectives on Autonomy, Agency and the Social Self. Oxford: Oxford University Press, pp. $\boldsymbol{e n}_{\text {. }}$

McCall, L. (2005) 'The Complexity of Intersectionality', Signs, 30 (3), 1771-800.

Munford, R. (2007) ' "Wake Up and Smell the Lipgloss": Gender, Generation and the (A)Politics of Girl Power', in S. Gillis, G. Howie and R. Munford (eds), Third Wave Feminism: A Critical Exploration. Houndmills: Palgrave Macmillan, p.e.....

Phillips, A. (2001) 'Feminism and Liberalism Revised: Has Martha Nussbaum Got It Right?', Constellations, 8 (2), $249-66$. Prokhovnik, R. (2002) Rational Woman: A Feminist Critique of Dichotomy. Manchester: Manchester University Press. Siegel, D. (2007) Sisterhood, Interrupted: From Radical Women to Grrls Gone Wild. New York: Palgrave Macmillan.

Spencer, J. (2007) 'Feminist Waves', in S. Gillis, G. Howie and R. Munford (eds), Third Wave Feminism: A Critical Exploration. Houndmills: Palgrave Macmillan, pp.e...e.

Stone, A. (2007) 'On the Genealogy of Women: A Defence of Anti-essentialism', in S. Gillis, G. Howie and R. Munford (eds), Third Wave Feminism: A Critical Exploration. Houndmills: Palgrave Macmillan, pe.e.e.

Weeks, K. (2011) The Problem with Work: Feminism, Marxism, Antiwork Politics and Postwork Imaginaries. Durham, NC: Duke University Press.

Witt, C. (2011) The Metaphysics of Gender. Oxford: Oxford University Press. 


\section{AUTHOR QUERY FORM}

Dear Author,

During the preparation of your manuscript for publication, the questions listed below have arisen. Please attend to these matters and return this form with your proof.

Many thanks for your assistance.

\begin{tabular}{|l|l|l|}
\hline $\begin{array}{l}\text { Query } \\
\text { References }\end{array}$ & \multicolumn{1}{|c|}{ Query } \\
\hline 1 & $\begin{array}{l}\text { AUTHOR: Gillis, Howie and Munford, 2005 has been } \\
\text { changed to Gillis et al. 2005 so that this citation matches } \\
\text { the Reference List. Please confirm that this is correct. }\end{array}$ \\
\hline 2 & $\begin{array}{l}\text { AUTHOR: Phillips has been changed to Phillips (2001) } \\
\text { so that this citation matches the Reference List. Please } \\
\text { confirm that this is correct. }\end{array}$ \\
\hline 3 & $\begin{array}{l}\text { AUTHOR: Dalla Costa and James has been changed to } \\
\text { Dalla Costa and James (1973) so that this citation } \\
\text { matches the Reference List. Please confirm that this is } \\
\text { correct. }\end{array}$ \\
\hline 4 & $\begin{array}{l}\text { AUTHOR: Please supply page ranges for the References } \\
\text { in the Reference List. }\end{array}$ \\
\hline
\end{tabular}


Required software to e-Annotate PDFs: Adobe Acrobat Professional or Adobe Reader (version 8.0 or above). (Note that this document uses screenshots from Adobe Reader $\mathrm{X}$ )

The latest version of Acrobat Reader can be downloaded for free at: http://get.adobe.com/reader/

Once you have Acrobat Reader open on your computer, click on the Comment tab at the right of the toolbar:

닙

This will open up a panel down the right side of the document. The majority of tools you will use for annotating your proof will be in the Annotations section, pictured opposite. We've picked out some of these tools below:

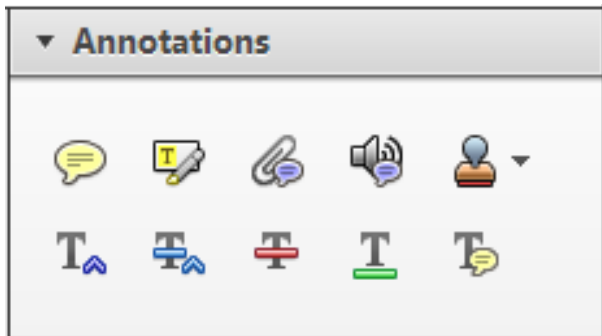

1. Replace (Ins) Tool - for replacing text.

Strikes a line through text and opens up a text box where replacement text can be entered.

\section{How to use it}

- Highlight a word or sentence.

- Click on the Replace (Ins) icon in the Annotations section.

- Type the replacement text into the blue box that appears.

Idard tramework for the analysis of $\mathrm{m}$ icy-Nevertheless, it also led to exog،

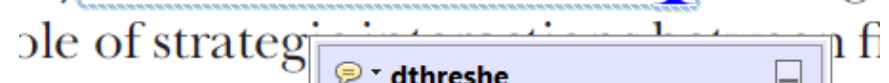
aber of comp 08/06/2011 15:58:17

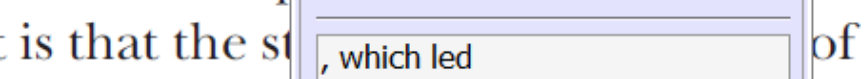
nain compo: be level, are exc nc

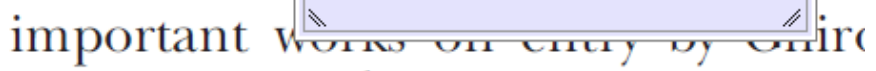
M heneferth) ${ }^{1}$ we anen the 'hlark $\mathrm{h}$

3. Add note to text Tool - for highlighting a section to be changed to bold or italic.

T Highlights text in yellow and opens up a text box where comments can be entered.

\section{How to use it}

- Highlight the relevant section of text.

- Click on the Add note to text icon in the Annotations section.

- Type instruction on what should be changed regarding the text into the yellow box that annears.

namic responses of mark ups ent with the VAR evidence

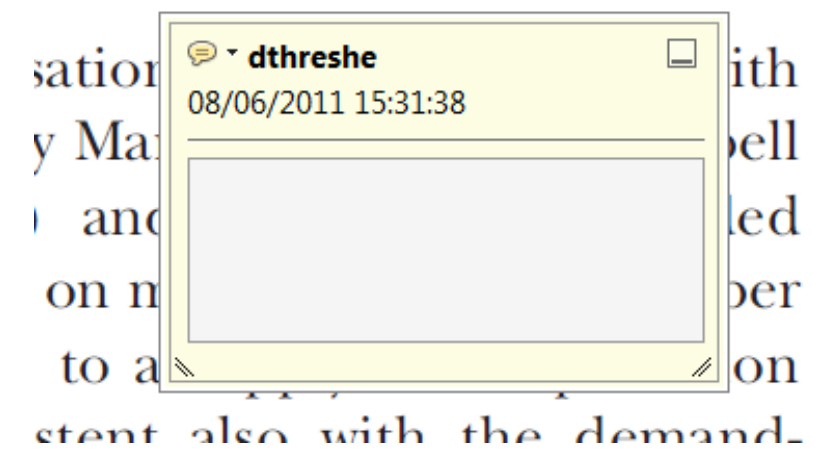

2. Strikethrough (Del) Tool - for deleting text.

Thikes a red line through text that is to be deleted.

\section{How to use it}

- Highlight a word or sentence.

- Click on the Strikethrough (Del) icon in the Annotations section.

there is no room tor extra prohts al c ups are zero and the number of ret) values are not determined by Blanchard and Kiyotaki (1987), rfect competition in general equilil ts of aggregate demand and supply lassical framework assuming monol eon an evorenois number of firms

\section{Add sticky note Tool - for making notes at} specific points in the text.

Marks a point in the proof where a comment needs to be highlighted.

\section{How to use it}

- Click on the Add sticky note icon in the Annotations section.

- Click at the point in the proof where the comment should be inserted.

- Type the comment into the yellow box that appears.

lallu allu suppiy silucks. hivst vi

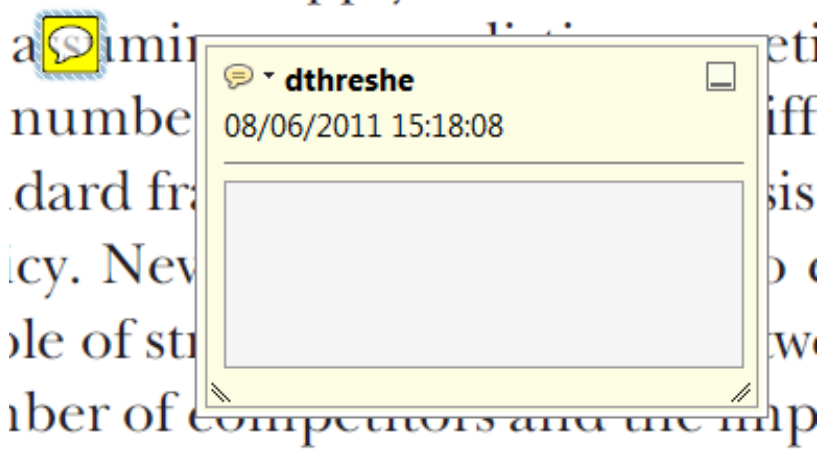

is that the structure of the secto 
5. Attach File Tool - for inserting large amounts of text or replacement figures.

Inserts an icon linking to the attached file in the appropriate pace in the text.

How to use it

- Click on the Attach File icon in the Annotations section.

- Click on the proof to where you'd like the attached file to be linked.

- Select the file to be attached from your computer or network.

- Select the colour and type of icon that will appear in the proof. Click OK.

E N D

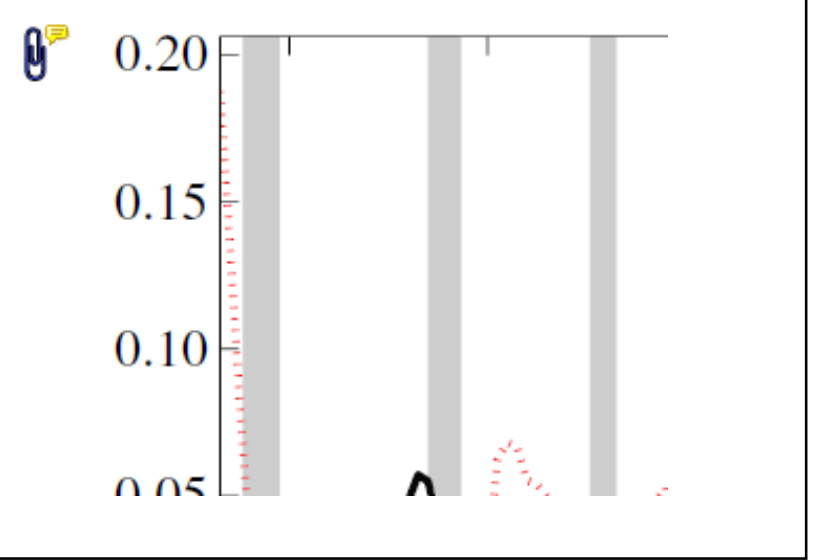

6. Add stamp Tool - for approving a proof if no corrections are required.

- Inserts a selected stamp onto an appropriate place in the proof

\section{How to use it}

- $\quad$ Click on the Add stamp icon in the Annotations section.

- $\quad$ Select the stamp you want to use. (The Approved stamp is usually available directly in the menu that appears).

- Click on the proof where you'd like the stamp to appear. (Where a proof is to be approved as it is, this would normally be on the first page).

of the Dusiness cycie, starting with the on perfect competition, constant ret

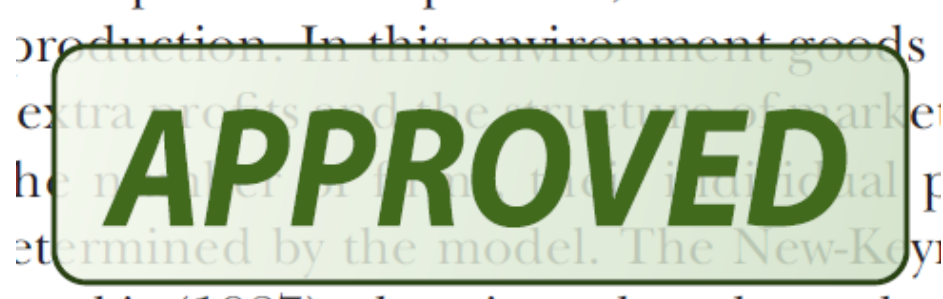

otaki (1987), has introduced produc general equilibrium models with nomin
- Drawing Markups

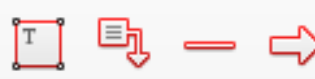

$0 \square \sqrt{6} D$

\section{How to use it}

- Click on one of the shapes in the Drawing Markups section.

- Click on the proof at the relevant point and draw the selected shape with the cursor.

- To add a comment to the drawn shape, move the cursor over the shape until an arrowhead appears.

- Double click on the shape and type any text in the red box that appears.
7. Drawing Markups Tools - for drawing shapes, lines and freeform annotations on proofs and commenting on these marks.

Allows shapes, lines and freeform annotations to be drawn on proofs and for comment to be made on these marks.

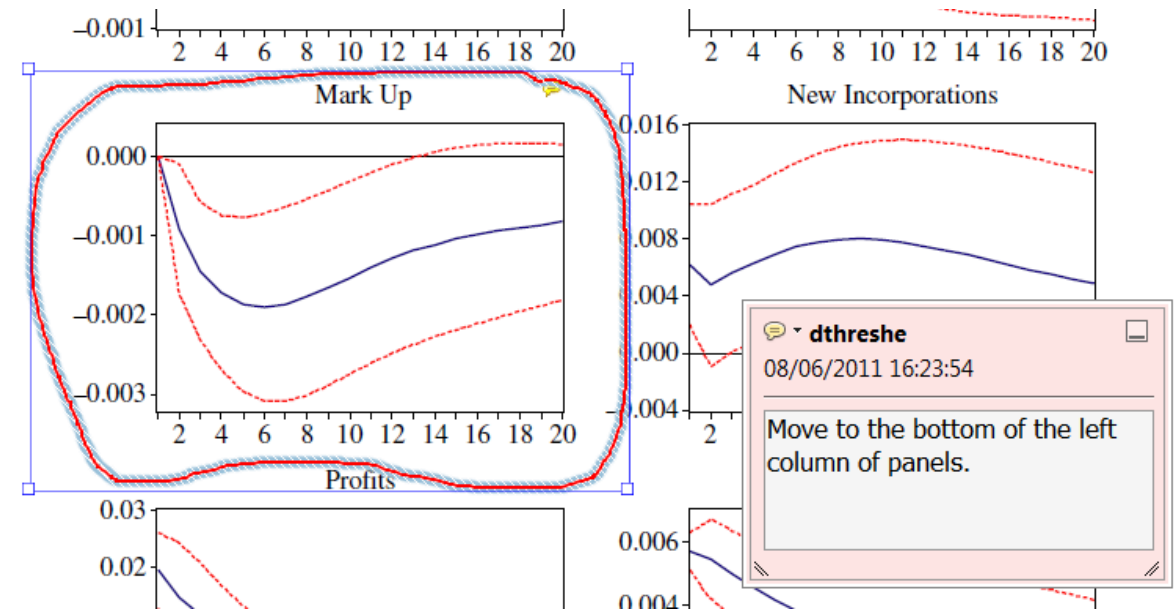

For further information on how to annotate proofs, click on the Help menu to reveal a list of further options:

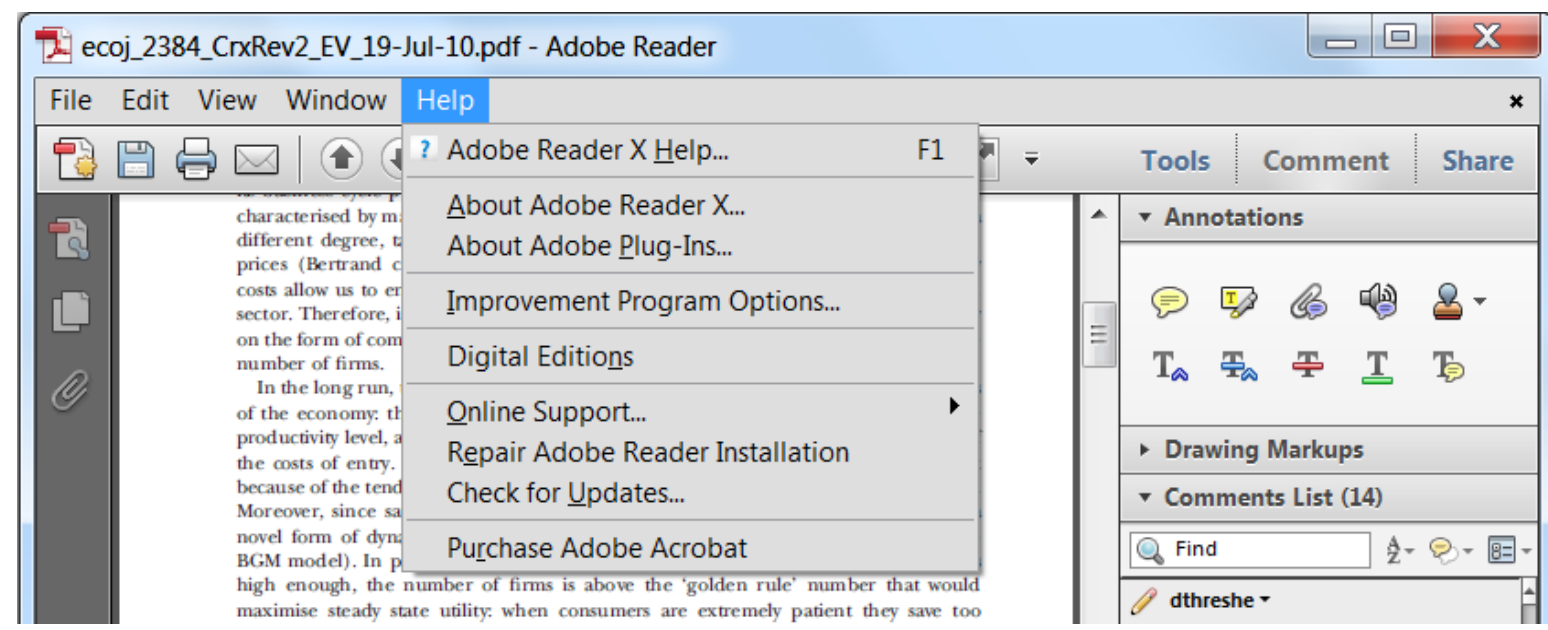

